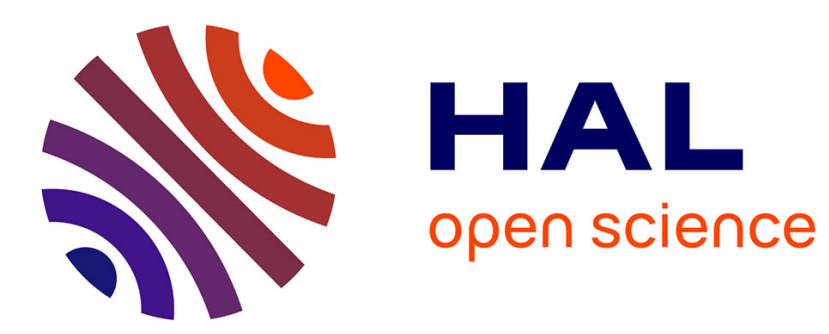

\title{
Reactions between ozone and building products: impact on primary and secondary emissions
}

\author{
Mélanie Nicolas, Olivier Ramalho, François Maupetit
}

\section{To cite this version:}

Mélanie Nicolas, Olivier Ramalho, François Maupetit. Reactions between ozone and building products: impact on primary and secondary emissions. 10th International Conference on Indoor Air Quality and Climate, Indoor Air'2005, Sep 2005, Beijing, China. pp.2118-2122. hal-00688538

\section{HAL Id: hal-00688538 https://hal.science/hal-00688538}

Submitted on 17 Apr 2012

HAL is a multi-disciplinary open access archive for the deposit and dissemination of scientific research documents, whether they are published or not. The documents may come from teaching and research institutions in France or abroad, or from public or private research centers.
L'archive ouverte pluridisciplinaire HAL, est destinée au dépôt et à la diffusion de documents scientifiques de niveau recherche, publiés ou non, émanant des établissements d'enseignement et de recherche français ou étrangers, des laboratoires publics ou privés. 


\title{
REACTIONS BETWEEN OZONE AND BUILDING PRODUCTS: IMPACT ON PRIMARY AND SECONDARY EMISSIONS
}

\author{
M Nicolas, O Ramalho, Maupetit* \\ Centre Scientifique et Technique du Bâtiment (CSTB), F-77447 Marne-la-Vallée, France
}

\begin{abstract}
The purpose of this study is to document the influence of reactions of ozone on building products and on their emissions in indoor air. For this purpose, 12 building products were exposed to ozone in a dedicated experimental setup. The measured ozone removal rate is relatively low on paint $(7 \%)$, linoleum (23\%), PVC flooring (26\%) and polystyrene acoustic tile $(27 \%)$ but increases on carpets ( $55 \%$ to $70 \%)$, wall papers (65\% to $75 \%)$, unpainted gypsum board $(72 \%)$ and pine wood board $(77 \%)$. Ozone deposition velocities on the tested products were calculated. When building products are exposed to $\sim 100 \mathrm{ppb}$ of ozone, their primary emissions are significantly modified and secondary emissions have been identified. In particular, increased emissions of formaldehyde, hexanal, heptanal, octanal and decanal have been measured during exposure to ozone of several of the tested products.
\end{abstract}

\section{INDEX TERMS}

Ozone, Building products, Secondary emissions, Deposition velocity, Indoor chemistry

\section{INTRODUCTION}

Without specific indoor sources such as photocopiers, laser printers or air purifiers, outdoor ozone is the main source of ozone indoors. But the indoor-to-outdoor ozone concentration ratio generally ranges from 0.2 to 0.7 indicating ozone-induced indoor chemistry (Weschler 2000). Since indoor environments feature large surface-to-volume ratio, ozone reactions on indoor surfaces are presumably a significant sink even if gas phase chemistry also occurs indoors (Nazaroff et al. 2003).

Ozone removal on different building products has been documented (Weschler et al. 1992, Morrison and Nazaroff 2000, Kleno et al. 2001, Nicolas et al. 2003, Grontoft and Raychaudhuri 2004). Reactions of ozone modify primary emissions of building products causing secondary emissions of aldehydes (Weschler et al. 1992, Morrison and Nazaroff 2002, Nicolas et al. 2003) and odorous compounds (Knudsen et al. 2003).

The aim of this study is to document the removal of ozone on different building products, its impact on primary volatile organic compounds (VOC) emissions and the identification of secondary emissions. For this purpose, 12 new and unused building products were selected and exposed to ozone on an experimental setup where their primary and secondary emissions can be characterized.

\section{METHODS}

The experimental setup is adapted from emission test chamber methods for the determination of VOC emissions from building products and made of inert materials (glass and PFA Teflon). The setup is made of two parallel lines, including a mixing chamber and a test chamber where the products are placed, supplied with clean humidified air (particles, silica gel, charcoal filtered). The first line (hereafter referred to as "reference line"), where building products are not exposed to ozone, is used for the characterization of their primary emissions whereas the second line (hereafter referred to as "ozone line"), where building products are exposed to ozone, is used for the characterization of their secondary emissions (Nicolas et al. 2003).

In the "ozone line", building products are exposed to $~ 100$ to $200 \mathrm{ppb}$ of ozone generated using pure oxygen (Air Liquide, $99.999 \% \mathrm{O}_{2}$ ) through an UV light generator (Pen Ray, model SOG 1). Ozone is monitored at the inlet and outlet of the "ozone line" test chamber using a photometric analyzer (Environnement SA, model $\mathrm{O}_{3} 41 \mathrm{M}$ ). The experimental conditions were kept constant during the tests (Table 1).

\footnotetext{
* Corresponding author email: f.maupetit@cstb.fr
} 
Table 1. Experimental parameters selected for the tests

\begin{tabular}{|c|c|}
\hline Experimental parameters & Selected conditions \\
\hline Ozone concentration at "ozone line" inlet & $100 \pm 5$ to $210 \pm 10 \mathrm{ppb}$ \\
Temperature & $23 \pm 2{ }^{\circ} \mathrm{C}$ \\
Relative humidity & $50 \pm 5 \%$ \\
Test chamber $\left(\mathrm{V}_{\mathrm{c}}\right)$ & Glass, $0.017 \mathrm{~m}^{3}$ \\
Air flow rate & $0.204 \mathrm{~m}^{3} \cdot \mathrm{h}^{-1}$ \\
Air exchange rate (AER) & $12 \mathrm{~h}^{-1}$ \\
Test duration & $24-48 \mathrm{~h}$ \\
\hline
\end{tabular}

VOC were measured according to the ISO/FDIS 16000-6 pre-standard using thermal desorption and gas chromatography (GC) coupled with mass spectrometry detector (MS) for identification and flame ionization detector (FID) for quantification (Perkin Elmer ATD 400, Varian 3800 / Saturn 2000). Sampling was performed using Tenax TA sorbent tubes (Perkin Elmer). VOC were semi-quantified using the toluene response factor.

Aldehyde compounds were measured using HPLC (Waters, model Alliance) according to the ISO 16000-3 standard. Sampling was performed using DNPH coated cartridges (Waters). No ozone scrubbers were used for sampling in the "ozone line" since ozone is partly removed on the products. The main observed bias due to aldehyde sampling in presence of ozone is an underestimation of benzaldehyde which is not the main secondary emitted compound.

Twelve new and unused building products were selected for those experiments: a linoleum and a PVC flooring, four carpets (rubber, textile, PVC and bitumen backing), two wall papers, a paint (applied on a polyester film), a polystyrene ceiling tile, a gypsum board and a pine wood board.

\section{RESULTS}

Mean ozone concentrations in the test chamber inlet and outlet during the experiments are illustrated on Figure 1 for the empty glass chamber and for the 12 selected products.

Before testing building products, we checked that the empty glass chamber was inert to ozone (ozone removal $<2$ $\%)$. The mean ozone removal is low on the paint (7\%) and relatively limited on the polystyrene acoustic tile (27 $\%$ ). The ozone removal is lower on resilient floorings ( $23 \%$ and $26 \%$ for the linoleum and PVC, respectively) than on textile floorings ( $55 \%$ to $70 \%$ ) presumably due to a higher specific surface for carpets. Relatively high ozone removals were measured on the two tested wall papers (65\% and $73 \%)$, on the gypsum board (72\%) and on the pine wood board $(77 \%)$.

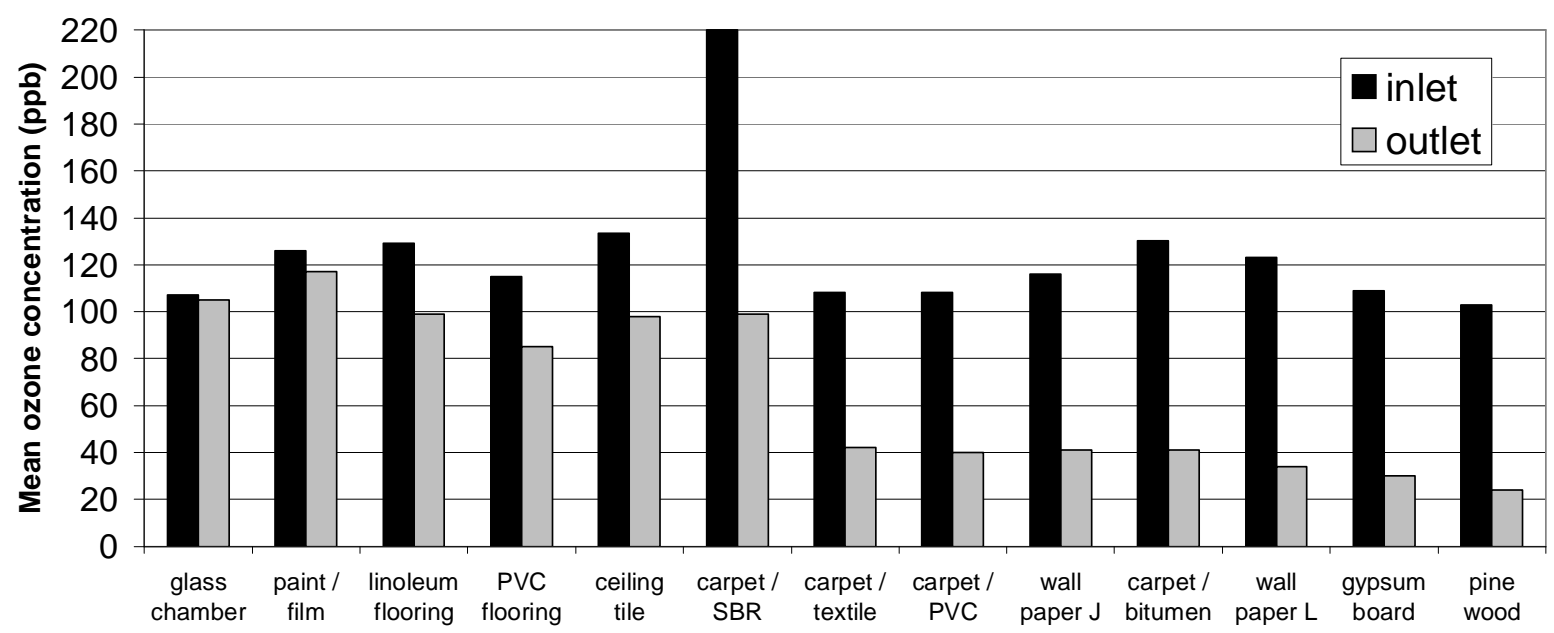

Figure 1. Mean ozone concentration (ppb) in the test chamber inlet and outlet 
Emissions of building products are characterized using their area specific emission rates $S E R_{a}\left(\right.$ in $\left.\mu \mathrm{g} \mathrm{m} \mathrm{m}^{-2} \mathrm{~h}^{-1}\right)$ according to equation (1), assuming that gas-phase reactions are negligible with the AER in the setup $\left(12 \mathrm{~h}^{-1}\right)$ :

$S E R_{a}=C_{V O C} \cdot \frac{A E R}{\frac{A_{b p}}{V_{c}}}$

where $C_{V O C}$ is the VOC concentration measured at the test chamber outlet $\left(\mu \mathrm{g} \mathrm{m}^{-3}\right), A E R$ the air exchange rate $\left(\mathrm{h}^{-1}\right)$, $A_{b p}$ the building product exposed surface $\left(\mathrm{m}^{2}\right)$ and $V_{c}$ the test chamber volume $\left(\mathrm{m}^{3}\right)$.

Table 2. Specific emission rates $\left(\mu \mathrm{g} \mathrm{m}^{-2} h^{-1}\right)$ of formaldehyde

\begin{tabular}{l|ccc|ccc}
\multicolumn{2}{c}{} & \multicolumn{3}{c}{ Reference line } & \multicolumn{3}{c}{ Ozone line } \\
\cline { 2 - 7 } & $0 \mathrm{~h}$ & $24 \pm 2 \mathrm{~h}$ & $48 \pm 4 \mathrm{~h}$ & $0 \mathrm{~h}$ & $24 \pm 2 \mathrm{~h}$ & $48 \pm 4 \mathrm{~h}$ \\
\hline Carpet / textile & 0.7 & 8.9 & 8.4 & 0.8 & 12.8 & 13.6 \\
Carpet / PVC & 0.7 & 31.5 & 27.5 & 1.1 & 45.1 & 41.1 \\
Carpet / bitumen & 0.6 & 6.8 & 10.5 & 0.6 & 10.5 & 8.3 \\
Carpet / rubber & 0.9 & 8.4 & 10.4 & 1.5 & 10.4 & 16.6 \\
PVC flooring & 0.6 & 1.7 & 1.7 & 0.6 & 6.9 & 6.5 \\
Linoleum flooring & 0.9 & 1.8 & 4.1 & 0.5 & 5.4 & 9.7 \\
Wall paper J & 0.6 & - & 3.8 & 0.8 & - & 38.5 \\
Wall paper L & 0.9 & 5.2 & 2.6 & 0.6 & 12.5 & 10.8 \\
Paint on polyester film & 1.8 & 11.0 & 12.0 & 1.0 & 23.8 & 16.1 \\
Pine wood board & 0.9 & 27.6 & 26.7 & 1.4 & 26.3 & 29.3 \\
Polystyrene ceiling tile & 0.5 & 0.5 & 0.5 & 0.6 & 13.9 & 6.5 \\
Gypsum board & 0.7 & 22.8 & 20.6 & 1.4 & 22.2 & 20.3
\end{tabular}

When comparing emissions of the products exposed or not to ozone, we observed significant modifications of their emissions for almost all tested products. Modifications of emissions can be either "consumption" of some compounds when their concentrations are lower in the ozone line than in the reference line or "production" of some compounds (secondary emissions) when concentrations in the ozone line are higher than in the reference line.

Table 3. Specific emission rates $\left(\mu \mathrm{g} \mathrm{m}^{-2} h^{-1}\right)$ of hexanal

\begin{tabular}{l|ccc|ccc}
\multicolumn{1}{c}{} & \multicolumn{3}{c}{ Reference line } & \multicolumn{3}{c}{ Ozone line } \\
\cline { 2 - 7 } & $0 \mathrm{~h}$ & $24 \pm 2 \mathrm{~h}$ & $48 \pm 4 \mathrm{~h}$ & $0 \mathrm{~h}$ & $24 \pm 2 \mathrm{~h}$ & $48 \pm 4 \mathrm{~h}$ \\
\hline Carpet / textile & 0.0 & 0.8 & 0.8 & 0.1 & 3.3 & 2.8 \\
Carpet / PVC & 0.0 & 0.6 & 0.8 & 0.1 & 8.6 & 8.9 \\
Carpet / bitumen & 0.5 & 0.8 & 3.2 & 0.5 & 3.2 & 2.4 \\
Carpet / rubber & 0.6 & 0.5 & 2.9 & 0.0 & 2.9 & 6.0 \\
PVC flooring & 0.5 & 0.5 & 0.6 & 0.5 & 15.4 & 13.7 \\
Linoleum flooring & 0.5 & 10.1 & 31.4 & 0.5 & 14.2 & 38.0 \\
Wall paper J & 0.6 & - & 0.4 & 0.5 & - & 12.4 \\
Wall paper L & 0.5 & 4.0 & 2.4 & 0.3 & 22.1 & 19.2 \\
Paint on polyester film & 0.4 & 310.7 & 294.0 & 0.4 & 416.7 & 266.7 \\
Pine wood board & 0.0 & 19.2 & 18.8 & 0.0 & 49.3 & 53.8 \\
Polystyrene ceiling tile & 0.8 & 0.7 & 0.6 & 0.5 & 0.0 & 0.7 \\
Gypsum board & 0.0 & 0.4 & 0.5 & 0.2 & 0.8 & 0.6
\end{tabular}


In particular, we observed lower concentrations in the ozone line than in the reference line of 4-phenylcyclohexene and $\mathrm{C} 12$ alkenes emitted from the carpet with textile backing, of 1-pentene-3-ol, 2-pentanone and acetic acid emitted from the linoleum flooring and of styrene emitted from the polystyrene ceiling tile. Since some of those compounds have unsaturated carbon-carbon bounds, their "consumption" is a potential indication of ozone-induced reactions. On the other hand, almost all tested products show higher emissions of aldehydes when exposed to ozone. Identified compounds representative of secondary emissions from building products are formaldehyde, hexanal, heptanal, octanal, nonanal (possible bias due to sampling on Tenax TA in presence of ozone), decanal, 2-nonenal (from carpet with rubber backing) and benzaldehyde (from linoleum and polystyrene tile). Formaldehyde and hexanal $\mathrm{SER}_{\mathrm{a}}$ for tested products exposed or not exposed to ozone are presented in Tables 2 and 3.

\section{DISCUSSION}

Deposition velocities of ozone on the tested products can be calculated from our experiments, assuming that gas-phase reactions are negligible at $12 \mathrm{~h}^{-1}$. This assumption may not be true for very reactive terpene compounds (Nazaroff and Weschler 2004). Therefore, the deposition velocity calculated for the pine wood board may be overestimated. In steady state conditions, the ratio of ozone concentrations in the inlet $\left(C_{\text {in }}\right)$ and outlet $\left(C_{\text {out }}\right)$ of the test chamber can be expressed using equation (2) (from Weschler 2000):

$$
\frac{C_{\text {out }}}{C_{\text {in }}}=\frac{A E R}{A E R+k_{d g c} \cdot \frac{A_{c}}{V_{c}}+k_{d b p} \cdot \frac{A_{b p}}{V_{c}}}
$$

where $A E R$ is the air exchange rate $\left(\mathrm{h}^{-1}\right), k_{d g c}$ the deposition velocity of ozone on glass in the test chamber $\left(\mathrm{cm} . \mathrm{s}^{-1}\right)$, $A_{c}$ the test chamber inner surface $\left(\mathrm{m}^{2}\right), V_{c}$ the test chamber volume $\left(\mathrm{m}^{3}\right), k_{d b p}$ the deposition velocity of ozone on the building product $\left(\mathrm{cm} . \mathrm{s}^{-1}\right)$ and $A_{b p}$ the building product exposed surface ( $\left.\mathrm{m}^{2}\right)$. In Eqn (2), the microstructure of the building product is not considered $\left(A_{b p}\right.$ represents the building product exposed surface and not its specific surface). $k_{d}(A / V)\left(\right.$ in $\left.^{-1}\right)$ represents the first-order removal rate constant of ozone on indoor surfaces (Weschler 2000).

Calculated surface removal rate constants and deposition velocities on the empty glass chamber and on the tested products are presented in Table 4. The higher ozone deposition velocities are calculated for the pine wood board (neglecting gas-phase reactions), the 2 tested wall papers, the gypsum board and 2 carpets. Ozone deposition velocities reported in this study are in good agreement with results from similar experiments (e.g. Kleno et al. 2001, Grontoft and Raychaudhuri 2004).

Table 4. Characteristics of selected building products and deposition velocities $\left(\mathrm{cm} \mathrm{s}^{-1}\right)$

\begin{tabular}{lcccc} 
& $\begin{array}{c}\text { Exposed surface } \\
\left(\mathrm{m}^{2}\right)\end{array}$ & $\begin{array}{c}\text { Loading factor } \\
A / V\left(\mathrm{~m}^{2} \mathrm{~m}^{-3}\right)\end{array}$ & $\begin{array}{c}\text { Surface removal } \\
\text { rate constant } \\
k_{d}(A / V)\left(\mathrm{h}^{-1}\right)\end{array}$ & $\begin{array}{c}\text { Deposition } \\
\text { velocity } k_{d} \\
\left(\mathrm{~cm} \mathrm{~s}^{-1}\right)\end{array}$ \\
\hline Empty glass chamber & 0.3 & 17.6 & 0.23 & 0.00036 \\
Carpet / textile & 0.16 & 9.4 & 19.0 & 0.056 \\
Carpet / PVC & 0.16 & 9.4 & 20.3 & 0.060 \\
Carpet / bitumen & 0.16 & 9.4 & 26.3 & 0.078 \\
Carpet / rubber & 0.16 & 9.4 & 14.7 & 0.043 \\
PVC flooring & 0.16 & 9.4 & 10.0 & 0.029 \\
Linoleum flooring & 0.16 & 9.4 & 3.6 & 0.011 \\
Wall paper J & 0.16 & 9.4 & 22.0 & 0.065 \\
Wall paper L & 0.16 & 9.4 & 31.9 & 0.094 \\
Paint on polyester film & 0.14 & 8.2 & 0.90 & 0.003 \\
Pine wood board & 0.17 & 10.1 & 39.7 & 0.109 \\
Polystyrene ceiling tile & 0.17 & 10.1 & 4.4 & 0.012 \\
Gypsum board & 0.22 & 12.6 & 31.2 & 0.068
\end{tabular}




\section{CONCLUSION AND IMPLICATIONS}

This study underlines the capacity of various building products frequently used in indoor settings to significantly remove ozone. Ozone deposition velocities of the different tested products were calculated and can be used for the estimation of indoor ozone concentration (from outdoors and without specific indoor source) in spaces where such products are installed. Ozone exposure also modifies primary emissions of the tested products and secondary emissions were identified. Indeed ozone exposure of building products generally increases their emissions of various carbonyl compounds. Some of those compounds are known irritants but ozone-induced reactions also appears to be a supplementary indoor source of formaldehyde which has been re-classified as carcinogenic compound category 1 by IARC in 2004. Therefore, specific indoor sources or the outdoor-to-indoor transfer of ozone appears to have a negative impact on indoor air quality.

\section{ACKNOWLEDGEMENTS}

This work has been supported by CSTB and the French Agence de l'Environnement et de la Maîtrise de l'Energie (ADEME) through 02-04-002 grant.

\section{REFERENCES}

Grontoft T. and Raychaudhuri MR. 2004. "Compilation of tables of surface deposition velocities for O3, NO2 and SO2 to a range of indoor surfaces". Atmospheric Environment. 38: 533-544.

Kleno JG., Clausen PA., Weschler CJ. and Wolkoff P. 2001. "Determination of ozone removal rates by selected building products using the FLEC emission cell”, Environmental Science \& Technology. 35: 2548-2553.

Knudsen HN., Nielsen PA., Clausen PA., Wilkins CK. and Wolkoff P. 2003. "Sensory evaluation of emissions from selected building products exposed to ozone", Indoor Air. 13: 223-231.

Morrison GC. and Nazaroff WW. 2000. "The rate of ozone uptake on carpets: Experimental studies", Environmental Science \& Technology. 34: 4963-4968.

Morrison GC. and Nazaroff WW. 2002. "Ozone interactions with carpet: Secondary emissions of aldehydes", Environmental Science \& Technology. 36: 2185-2192.

Nazaroff WW., Weschler CJ. and Corsi RL. 2003. "Indoor air chemistry and physics”, Atmospheric Environment. 37: 5451-5453.

Nazaroff WW and Weschler CJ. 2004. "Cleaning products and air fresheners: Exposure to primary and secondary air pollutants", Atmospheric Environment. 38: 2841-2865.

Nicolas M., Ramalho O. and Maupetit F. 2003. "Experimental study of reactions between ozone and building products", Proceedings of the 7th International Conference Healthy Buildings 2003, Singapore: Healthy Buildings 2003, Vol 2, pp 343-348.

Weschler CJ., Hodgson AT. and Wooley JD. 1992. "Indoor chemistry: Ozone, volatile organic compounds and carpets", Environmental Science \& Technology. 26: 2371-2377.

Weschler CJ. 2000. “Ozone in indoor environments: Concentration and chemistry”, Indoor Air. 10: 269-288. 